Сидорчук О. Г., sydorko91@gmail.com, ORCID ID:0000-0002-7078-1557, Researcher ID: C-4723-2016

д.е.н., доц., дочент Львівського регіонального інституту державного управління Національної академії державного управління при Президентові Украӥни, м. Львів

\title{
ПРОЯВИ СОЦІАЛЬНОЇ НЕБЕЗПЕКИ В УМОВАХ ГЛОБАЛЬНИХ СОЦАЛЬНИХ КРИЗ
}

\begin{abstract}
Анотація. Статтю присвячено виявленню цільових орієнтирів інституційного забезпечення соціальної безпеки громадян і суспільства в иілому за умови непереборної дї соиіальних криз. За результатами опитування громадської думки виявлено основні пріоритети громадян щчодо сочіальної безпеки, щчо включають сприятливі та безпечні умови життя, гідний рівень якості життя, упевненість у майбутньому, захищеність прав $i$ свобод громадян. Натомість поза кризою громадяни надавали менше значення проблемам зайнятості, доступності та якості медичних послуг, забезпечення здорового способу життя. Визначені особливості зайнятості свідчать про незбалансованість, щзо проявляється у підвищеному попиті на працівників низького рівня кваліфікачіï, щзо підриває мотивацію до професійного зростання та розвитку, супроводжуючись значними втратами людського і трудового капіталу та сочіальною апатією. Водночас дослідження показало, щзо незадовільна заробітна плата, зайнятість, безробіття, дисбаланс на ринку праџі спричиняють загрози соціальному забезпеченню, такі як низька зайнятість у певних вікових групах, особливо молоді, включаючи освіту та професійне навчання. Загрози, щьо виникли, та рівень безробіття, у тому числі довгострокового, формують умови для несприятливого сочіального середовища та стають джерелом соиіальної напруги в суспільстві. Виявлено, щчо пандемічний спалах на початку 2020 р. змістив пріоритети у суспільному сприйнятті соціальних небезпек, спричинивши значне падіння економіки, обсягів торгівлі, цінові коливання, зростання рівня безробіття та зменшення доходів більшої частки населення, щзо негативно позначилося на рівні життя громадян. Показано, щчо в умовах глобальних соиіальних криз та форс-мажорних обставин пріоритетом держсвного піклування стають найменш захищені верстви населення, тобто одночасно виявляються різні варіації впливу соціального забезпечення держави. У подальших дослідженнях дочільно виявити можливі інструменти реалізації соціальної політики для своєчасного та ефективного запобігання небезпечним сочіальним проявам
\end{abstract}

Ключові слова: соціальна безпека, соціальна політика, рівень якості життя, інституційний вплив, зайнятість, безробіття, людський капітал.

Sydorchuk O. H., sydorko91@gmail.com, ORCID ID: 0000-0002-7078-1557, Researcher ID: C-4723-2016,

Doctor of Economics, Associate Professor, Associate Professor of the Lviv Regional Institute of Public Administration of the National Academy of Public Administration under the President of Ukraine, Lviv

\section{MANIFESTATIONS OF SOCIAL DANGER IN THE CONDITIONS OF GLOBAL SOCIAL CRISES}

\begin{abstract}
The article is devoted to identifying the targets of institutional support for social security of citizens and society as a whole under the conditions of insurmountable social crises. According to public opinion polls, the main priorities of citizens in terms of social security are determined, including favorable and safe living conditions, decent standard of living, confidence in the future, protection of rights and freedoms of citizens. Instead, outside the crisis, citizens attached less importance to the problems of employment, accessibility and quality of medical services, ensuring a healthy lifestyle. Certain features of employment indicate an imbalance, which is manifested in increased demand for low-skilled workers, which undermines the motivation for professional growth and development, accompanied by significant losses of human and labor capital and social apathy. At the same time, the study proved that unsatisfactory wages, employment, unemployment, imbalances in the labor market cause social security threats, such as low employment in certain age groups, especially young people, including education and professional training. Certain features of employment indicate an imbalance, which is manifested in increased demand for low-skilled workers, which undermines the motivation for professional growth and development, accompanied by significant losses of human and labor capital and social apathy. The threats that have arisen and the level of unemployment, including long-term, create conditions for an unfavorable social environment and become a source of social tension in society. It was found that the pandemic outbreak in early 2020 shifted priorities in the public perception of social dangers, causing a significant decline in the economy, trade, price fluctuations, rising unemployment and declining incomes of the majority of the
\end{abstract}


population, which negatively affected living standards. It is shown that in the conditions of global social crises and force majeure the priority of state care becomes the least protected segments of the population and different variations of influence of social security of the state are simultaneously detected. In further research, it is advisable to identify possible tools for implementing social policy for timely and effective prevention of dangerous social manifestations.

Keywords: social security, social policy, quality of life, institutional impact, employment, unemployment, human capital.

$$
\begin{aligned}
& \text { JEL Classification: H31, H41, H51, I38, J64 } \\
& \text { DOI: https://doi.org/10.36477/2522-1205-2020-59-07 }
\end{aligned}
$$

Постановка проблеми. Ключовою особливістю розвитку сучасного суспільства є соціалізація всіх сфер людського життя та підпорядкування їх соціальним цілям. У Декларації соціального прогресу і розвитку ООН наголошується, що міжнародний мир та безпека, з одного боку, та соціальний прогрес і економічний розвиток - 3 іншого, перебувають у тісному взаємозв'язку та взаємно впливають одне на одного. Відтак соціальна безпека виступає ключовою передумовою не лише соціального, але й економічного прогресу країни. Разом 3 тим, у правовому полі України немає офіційного визначення категорії “соціальна безпека". В умовах мінливого внутрішнього і зовнішнього середовища забезпечення ефективного функціонування i розвитку особистості та суспільства потребує державної політики, спрямованої на збереження і розвиток людського потенціалу, ефективне функціонування системи життєзабезпечення населення, узгодження інтересів і потреб усіх суб'єктів соціального захисту. Чутливість людини до небезпек лише зростає 3 ускладненням ii соціальної організації та підвищенням якості життя. Продукування ризиків відбувається в усіх суспільних сферах: економічній, політичній, соціальній. Вони зумовлені дією багатьох природних, інформаційно-комунікативних, соціальних і технологічних процесів, на розгортання яких впливає цілий ряд непрогнозованих, випадкових об'єктивних та суб'єктивних чинників. Забезпечення соціальної безпеки людини, суспільства i держави $є$ центральним концептом, навколо якого має бути структурована діяльність усіх гілок влади, адже саме гарантування соціальної безпеки є необхідною передумовою позитивного сприйняття суспільством діяльності владних інституцій та успішної реалізації проголошених в Україні реформ.

Аналіз останніх досліджень і публікацій. Головною метою соціальної безпеки більшість вітчизняних дослідників вважають розробку та реалізацію системи соціальних гарантій, однак підходи до інструментів їі інституційного забезпечення серед науковців значно різняться. Так, Р. Підлипна, трактуючи соціальну безпеку як стан захищеності соціальних інтересів особи і суспільства, пропонує виокремлювати статичний та наслідковий підходи [13] до визначення загроз соціальній безпеці, О. Новікова [11] обгрунтовує підходи та пріоритетні напрями соціальної політики, спрямовані на подолання соціальних наслідків системної кризи та формування соціальних перспектив розвитку людини, суспільства, країни. Н. Коленда [8] безпосередньо пов'язує з соціальною безпекою категорію якості життя, а Т. Васильців та Р. Лупак [1] пропонують в якості стратегічних пріоритетів конвергенції соціальної безпеки розглядати соціальні інтереси. Харазішвілі Ю. М. та Грішнова О. А. виділяють чотири групи функціональних складників соціальної безпеки: безпека трудового потенціалу, безпека соціальної сфери, безпека ринку праці та зайнятості населення, безпека міграційної безпеки [14]. І. Нечаєва пропонує шляхи реформування системи соціального страхування для зміцнення соціальноекономічної безпеки в умовах перманентної кризи [10]. Попри доволі широке висвітлення соціальних проблем i шляхів їх інституційного подолання, практично відсутні відомості щодо державного реагування на виникнення масштабних соціальних криз непереборної дії.

Постановка завдання. Основною метою дослідження є виявлення цільових орієнтирів та основних шляхів інституційного регулювання рівня соціальної безпеки в умовах настання глобальних соціальних криз.

Виклад основного матеріалу дослідження. 3 макроекономічної точки зору соціальна безпека являє собою систему управління соціальними ризиками для компенсації шкоди, зменшення або запобігання їх впливу на державу, суспільство та громадян. Як соціально-економічна категорія, соціальна безпека охоплює відносини щодо перерозподілу національного доходу $з$ метою забезпечення визначених соціальних стандартів життя для кожної людини в умовах дії соціальних ризиків. Інтегроване поняття соціальної безпеки включає стан і можливості захищеності соціальних інтересів людини, суспільства, держави від впливу зовнішніх та внутрішніх загроз і грунтується на гарантіях правового та інституціонального захисту інтересів суб'єктів соціальних відносин, що забезпечуються за рахунок попередження соціальних ризиків та пом'якшення їх наслідків.

У світовій практиці соціальна безпека має переважно прикладне, інструментальне значення, пов'язане зі створенням та функціонуванням державних систем соціальної підтримки людей із суспільно неадекватним низьким рівнем доходів [6]. Чітко окреслений “безпековий” контент можна спостерігати лише у значенні захисту (social safety) та у парадигмі безпеки (social security) як економічної безпеки суспільства в контексті випадків, коли люди стикаються з певними соціальними ризиками. 


\section{Herald of Lviv University of Trade and Economics. Economic Sciences. № 59, 2020}

Соціальні ризики розглядаються як у широкому, так і у вузькому розумінні [7]. Соціальні ризики у вузькому розумінні - це ризики, які виникають через об'єктивні причини та проявляються як масові загрози, наприклад голод, масові епідемії, війна, бойові конфлікти, тероризм тощо. Соціальними ризиками, які формують загрози соціальної небезпеки, є такі: втрата здоров'я, працездатності; втрата роботи; втрата доходів та матеріального забезпечення; недоступність до базових соціальних послуг; вичерпаність ресурсів відтворення населення, робочої сили тощо; незахищеність у старості, соціальне виключення та ін. У широкому - це можливість прояву таких явищ і процесів, що погіршують соціальне становище суспільства чи людини через втрату життя та здоров'я, роботи, засобів існування, достатності доходів, прояви бідності чи депривацій, соціальну ізоляцію тощо [15]. Більш узагальнено під соціальними ризиками розуміють небезпеки та загрози, які обмежують економічну самостійність людини, можливості розвитку особистості та держави, зменшують соціальне благополуччя, супроводжуються негативними змінами та погіршенням соціального стану суспільства чи окремої людини [11].

Формування загроз соціальної безпеки виокремлює лише ті, які дійсно прямо або опосередковано значною мірою впливають на рівень соціальної безпеки та можливості їі дестабілізації. Загрози соціальної безпеки створюються такими видами ризиків, які пов'язані з втратою життя та здоров'я, роботи, особливо на довготривалий період, працездатності та засобів для існування, економічною та соціальною незахищеністю, соціальною ізоляцією, бідністю населення та соціальним виключенням. Соціальні ризики, які впливають на стан і рівень соціальної безпеки, вимірюються кількісно [3]. Для цього необхідно розглядати ступінь прояву ризику за трьома напрямами вимірювання:

- як вірогідність прояву конкретного виду соціального ризику;

- як втрати або наслідки, яких зазнаватиме суспільство чи людина за умови реалізації та прояву соціального ризику;

- як рівень економічної незахищеності від прояву соціальних ризиків.

У 2016 р. Україна ратифікувала Конвенцію Міжнародної організації праці про мінімальні норми соціального забезпечення № 102 [2], що визначає традиційні ризики втрати або зменшення доходу внаслідок об'єктивних обставин (хвороби, безробіття, старості, трудового каліцтва, професійного захворювання, утримання дітей, вагітності та пологів, інвалідності, втрати годувальника). Ці соціальні ризики враховуються при наданні соціальних виплат через систему соціального страхування, у фінансуванні якої беруть участь застраховані особи.

За результатами проведеного нами у листопаді 2019 р. опитування громадської думки (проводилося методом телефонного опитування абонентів фіксованого телефонного зв'язку, об'єм вибірки склав 2515 респондентів у 110 населених пунктах Львівської, Житомирської, Полтавської та Харківської областей України, статистична похибка вибірки (ймовірність 0,95, дизайн-ефект 1,5) не перевищувала 3,2\% для показників, наближених до $50 \%$, і не менша 0,7\% для показників, наближених до 1\% і 99\%), основними соціальними проблемами, які найбільше турбують українців, є: військовий конфлікт на сході України $(54,4 \%)$; низький рівень зарплат і пенсій $(54,1 \%)$; підвищення тарифів на комунальні послуги $(48,1 \%)$; підвищення цін на основні товари, інфляція $(34,9 \%)$; безробіття, відсутність роботи $(26,8 \%)$; хабарництво та корупція у владі (25,5\%); а також неможливість здобути якісне медичне обслуговування (19\%). Це саме ті показники, які визначають стан соціальної безпеки і суспільства, і держави, а також обумовлюють стан соціальної безпеки людини. За переконаннями респондентів, соціальна безпека проявляється перш за все у сприятливих та безпечних умовах життя $(63,8 \%)$, гідному рівні та якості життя $(56,2 \%)$, соціально-психологічній стійкості й упевненості у своєму майбутньому (39\%), захищеності прав і свобод громадян (33,3\%).

Показовим виявився той факт, що зайнятість, доступність до якісних медичних та освітніх послуг, забезпечення здорового способу життя не виступають першочерговими у прояві соціальної безпеки людини. Тим не менше 74,2\% респондентів констатували, що їм складно знайти роботу за своєю кваліфікацією та з достатнім заробітком (рис. 1), a 20,8\% протягом останніх трьох років були не задоволені своєю роботою в цілому. Кожен сьомий $(14,6 \%)$ з опитаних планував найближчим часом поїхати за кордон на тимчасові заробітки.

Визначені особливості зайнятості мають у цілому для країни досить негативні наслідки. 3 одного боку, вони свідчать про незбалансованість ринків освітніх послуг та ринку праці - зберігається підвищений попит на працівників більш низького рівня кваліфікації, а з іншого, - незатребуваність підриває мотивацію, особливо молоді, до професійного зростання та розвитку, що супроводжується значними втратами як людського, так і трудового потенціалу, капіталу, соціальною апатією та формує міграційні настрої. 


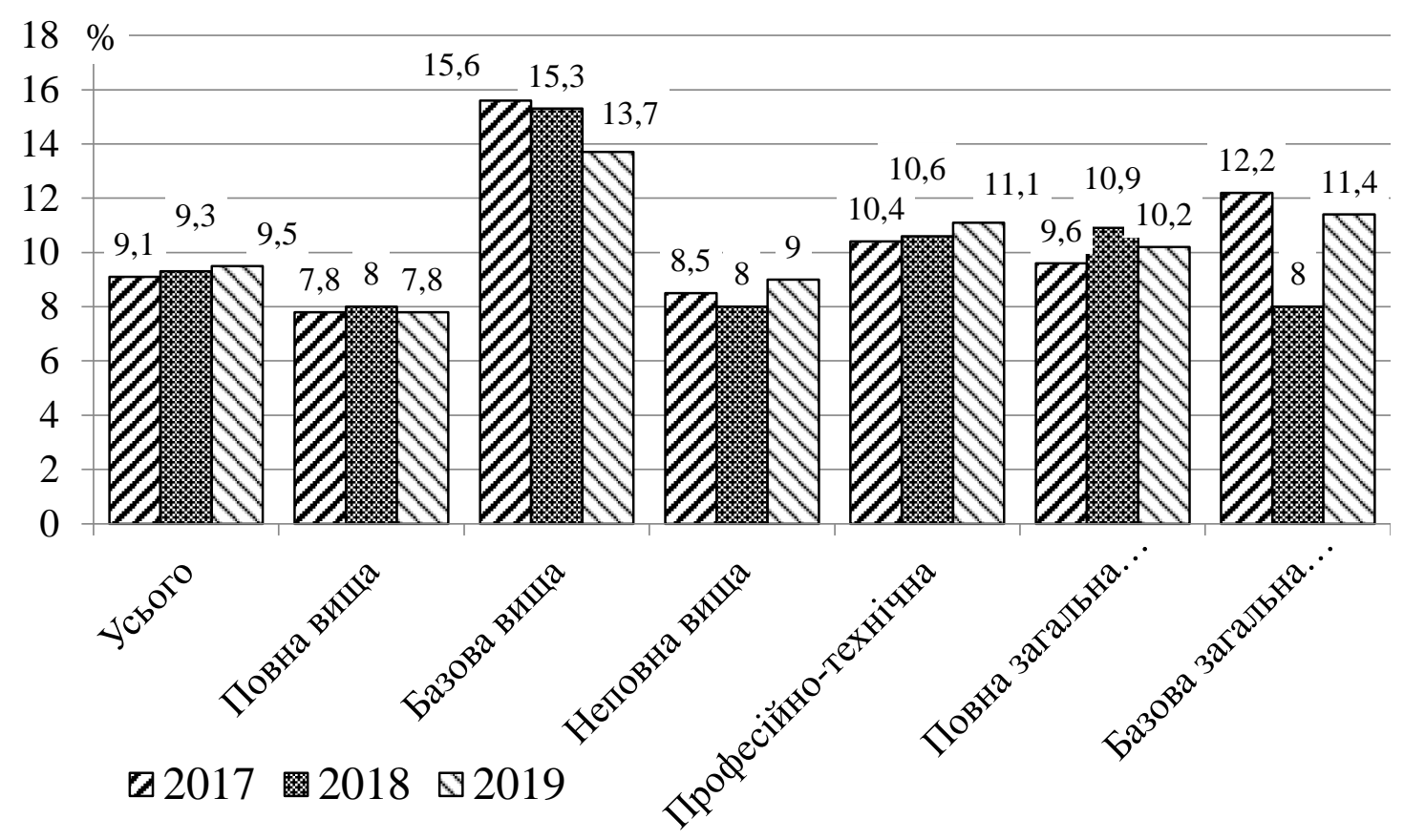

Рис. 1. Рівень безробіття серед економічно активного населення відповідного рівня освіти у 2017-2019 роках

Джерело: Розраховано за даними [4]

Таблиия 1

Динаміка макроекономічних показників розвитку України у 2015-2019 роках

\begin{tabular}{|l|c|c|c|c|c|c|}
\hline \multicolumn{1}{|c|}{ Показники } & 2015 & 2016 & 2017 & 2018 & 2019 & $\begin{array}{c}2019 / \\
2015, \\
\%\end{array}$ \\
\hline ВВП у фактичних цінах, млрд грн & 1988,5 & 2383,2 & 2982,9 & 3558,7 & 4080,2 & 205,2 \\
\hline Індекси інфляції, \% & 143,3 & 112,4 & 113,7 & 109,8 & 104,1 & 72,6 \\
\hline Індекси промислової продукції, \% & 87,7 & 104 & 101,1 & 103 & 99,5 & 113,5 \\
\hline Обсяг інвестицій, млрд грн & 219,4 & 273,1 & 359,2 & 448,5 & 578,7 & 263,8 \\
\hline Обсяг експорту, млрд дол. США & 46,6 & 44,9 & 52,3 & 59,2 & 65,3 & 140,1 \\
\hline Рівень безробіття, \% & 9,5 & 9,7 & 9,9 & 9,1 & 8,6 & 90,5 \\
\hline
\end{tabular}

Джерело: Розраховано за даними [5; 9]

Водночас на початку 2020 р. суспільство зіткнулося 3 новим соціальним викликом, спричиненим пандемічною загрозою, що призвело до значної переорієнтації акцентів соціальної безпеки через стрімку втрату робочих місць і зниження регулярних доходів більшості домогосподарств. Спалах пандемії Covid-19, спричинивши значне падіння світової економіки, обсягів торгівлі та цінові коливання, негативно позначився на стані соціальної безпеки українських громадян. Попри те, що криза в реальному секторі негативно позначилася на обсягах виробництва, капітальних інвестиціях і показниках зайнятості населення, що погіршило фінансовий стан значної частини підприємств і домогосподарств, слід зазначити, що доволі високі макропоказники (табл. 1) дозволили значно пом'якшити негативний вплив пандемії на соціальне функціонування держави.

Незадовільний рівень оплати праці, зайнятість, безробіття, незбалансованість на ринку праці обумовлюють створення загроз соціальної безпеки, таких як низький рівень зайнятості за окремими віковими групами, особливо молоді, у тому числі відповідно до освіти та професійно-кваліфікаційного рівня. Спричиняє виникнення загроз і рівень безробіття, у тому числі тривалого, який визначає умови для несприятливого соціального середовища та стає джерелом соціального напруження в суспільстві.

У 2019 р. сукупні доходи населення склали 3699,3 млрд грн (в середньому 67528 грн на одну особу), витрати становили 3815,5 млрд грн. В структурі доходів переважали заробітна плата $(47,4 \%)$, соціальні допомоги та інші одержані поточні трансферти $(31,7 \%)$, натомість на прибуток та змішаний дохід припадало $18,3 \%$, а на одержані доходи від власності - лише $2,6 \%$ всіх доходів. В структурі витрат 92,1\% припадало на споживчі витрати (табл. 2). 
Herald of Lviv University of Trade and Economics. Economic Sciences. № 59, 2020

Таблиия 2

Доходи та витрати населення у I-IV кварталах 2019 року (млн грн)

\begin{tabular}{|l|c|c|c|c|c|}
\hline & I кв. & II кв. & III кв. & IV кв. & Рік \\
\hline Доходи, всього & 814768 & 907970 & 963237 & 1013371 & 3699346 \\
\hline Заробітна плата & 401945 & 440702 & 449031 & 461659 & 1753337 \\
\hline Прибуток та змішаний дохід & 121813 & 143321 & 217903 & 195238 & 678275 \\
\hline Доходи від власності (одержані) & 15668 & 15816 & 24383 & 38614 & 94481 \\
\hline $\begin{array}{l}\text { Соціальні допомоги та інші одержані по- } \\
\text { точні трансферти, у т.ч. }\end{array}$ & 275342 & 308131 & 271920 & 317860 & 1173253 \\
\hline соціальні допомоги & 130259 & 146140 & 139588 & 143321 & 559308 \\
\hline інші поточні трансферти & 35678 & 43094 & 40747 & 42445 & 161964 \\
\hline соціальні трансферти в натурі & 109405 & 118897 & 91585 & 132094 & 451981 \\
\hline Витрати та заощадження, всього & 814768 & 907970 & 963237 & 1013371 & 3699346 \\
\hline Придбання товарів та послуг & 770930 & 828636 & 854527 & 952109 & 3406202 \\
\hline Доходи від власності (сплачені) & 9140 & 9784 & 10420 & 9929 & 39273 \\
\hline $\begin{array}{l}\text { Поточні податки на доходи, майно та інші } \\
\text { сплачені поточні трансферти, у т.ч. }\end{array}$ & 81406 & 91450 & 96238 & 100942 & 370036 \\
\hline поточні податки на доходи, майно тощо & 64329 & 73288 & 76870 & 81280 & 295767 \\
\hline внески на соціальне страхування & 916 & 884 & 992 & 1050 & 3842 \\
\hline інші поточні трансферти & 16161 & 17278 & 18376 & 18612 & 70427 \\
\hline Нагромадження нефінансових активів & -10159 & -11666 & 9069 & -8392 & -21148 \\
\hline Приріст фінансових активів, з них & -36549 & -10234 & -7017 & -41217 & -95017 \\
\hline $\begin{array}{l}\text { приріст грошових вкладів та заощаджень у } \\
\text { цінних паперах }\end{array}$ & -9675 & 28621 & 1660 & 46846 & 67452 \\
\hline заощадження в іноземній валюті & 6901 & 12653 & 16611 & 17001 & 53166 \\
\hline $\begin{array}{l}\text { позики, одержані за виключенням } \\
\text { погашених (-) }\end{array}$ & 7534 & 2850 & 6117 & 7834 & 24335 \\
\hline Наявний дохід & 614817 & 687839 & 764994 & 770406 & 2838056 \\
\hline Заощадження (приріст) & -46708 & -21900 & 2052 & -49609 & -116165 \\
\hline Наявний дохід на одну особу, грн & 14598 & 16345 & 18190 & 18331 & 67528 \\
\hline
\end{tabular}

Джерело: Розраховано за даними [5]

Незначне зниження темпів зростання реального наявного доходу українських домогосподарств через сповільнення приросту заробітної плати спостерігалося ще у 2019 р. Несправедлива оплата праці також може сприяти створенню загроз соціальної безпеки за умови, якщо іiі рівень унеможливлює забезпечення працюючого та його сім’ї засобами існування [17]. Основні чинники формування соціальних загроз у системі оплати праці пов'язані в першу чергу 3 низьким рівнем оплати праці, що обумовлює розповсюдження бідності серед працюючого населення. Незадіяність молоді у трудовій сфері або низька оплата праці супроводжується поширенням утриманських настроїв, деформацією ціннісних орієнтацій у суспільстві [16] та підриває мотивацію до економічної активності. Отож, значну загрозу ми вбачаємо в тому, що, починаючи з квітня 2020 р., намітилися такі загрозливі тенденції, як втрата доходів і роботи значною частиною громадян та скорочення регулярних доходів у понад третини українських родин (рис. 2).

Соціально-економічні загрози, які формуються та проявляються у трудовій сфері, пов'язані не тільки з низьким рівнем оплати праці як основного джерела доходів. Дуже важливою складовою $\epsilon$ формування соціальних ризиків, пов'язаних із довготривалим безробіттям, яке супроводжується скороченням шансів на працевлаштування, професійною декваліфікацією та знеціненням людського капіталу, послабленням мотивації, ерозією трудової етики, погіршенням фізичного та морального здоров'я індивідів протягом періоду безробіття. Основними наслідками довготривалого безробіття на макрорівні можуть бути процеси, пов'язані зі зростанням бідності, маргіналізації населення, вони супроводжуються посиленням соціальної напруженості, підвищенням імовірності політичних та соціальних потрясінь. Для людини, особистості та іiі сім'ї це в першу чергу розрив соціальних зв'язків, зростання ймовірностей формування та реалізації девіантної поведінки тощо. Тому особливе занепокоєння викликає факт, що до кінця травня 2020 р. кількість зареєстрованих безробітних зросла в півтора рази порівняно $з$ докарантинним періодом і становила на 1 червня 2020 р. 511388 осіб (у попередньому році - 300875 осіб). Водночас станом на 1 червня 2020 р. у державній службі зайнятості було зареєстровано 58591 вакансію (у попередньому році - 96160 вакансій). Таким чином, на одне вакантне місце на момент послаблення карантинних обмежень претендувало 9 осіб [4]. 


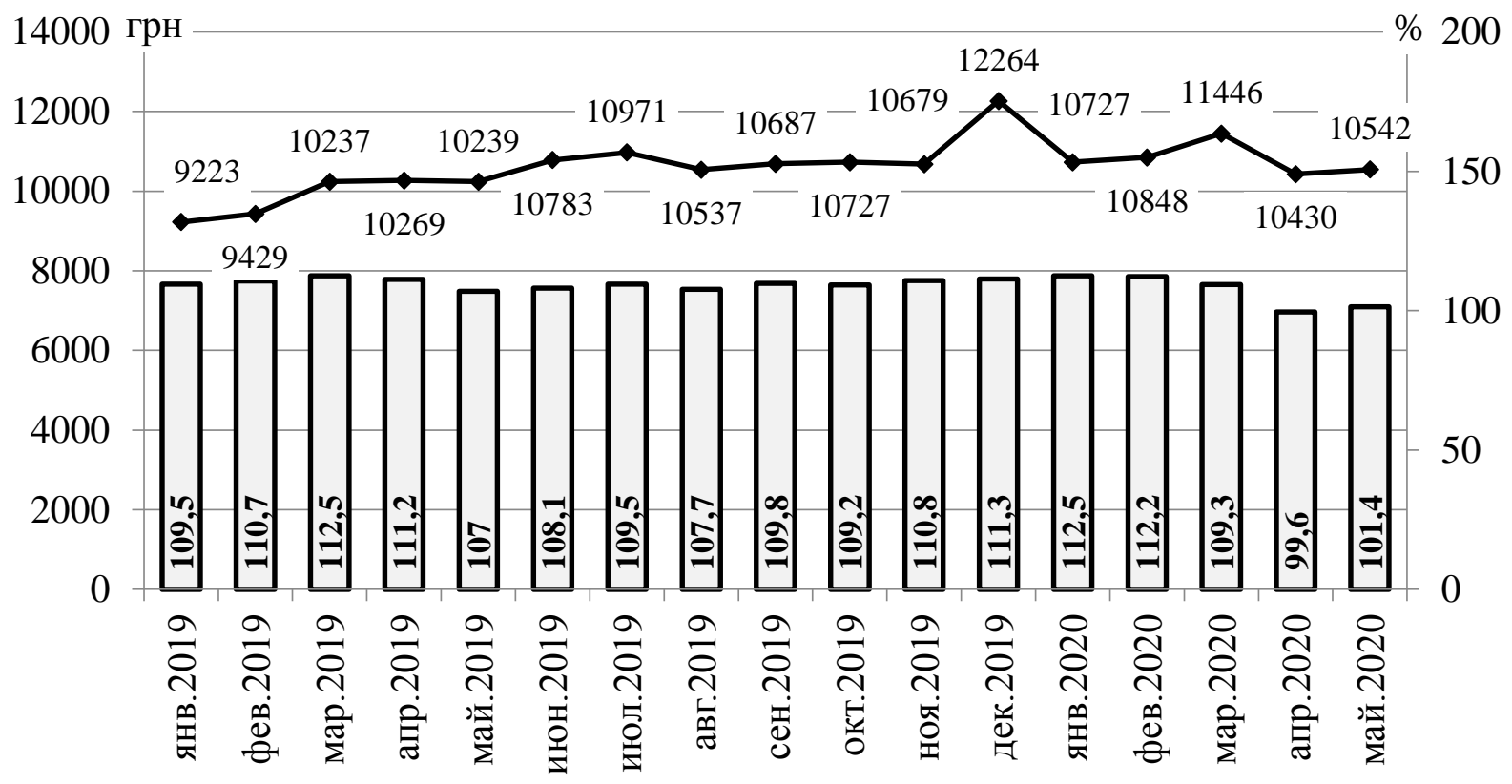

\section{$\square$ Реальна заробітна плата, \% до відповідного місяця попереднього року \\ $\rightarrow$ - Номінальна заробітна плата, грн.}

Рис. 2. Динаміка середньої заробітної плати в Україні у 2019-2020 роках

Джерело: Розраховано за даними [5]

Відповідно, на державному рівні було прийнято рішення про збільшення обсягів соціальної допомоги соціально незахищеним верствам населення, зокрема здійснено доплати до пенсій. Водночас скорочення виробництва призвело до зменшення дохідної частини бюджету і ресурсів Пенсійного фонду України [12], що значно обмежило інституційні можливості надання соціальної допомоги населенню. Отож, урядом було ініційовано проекти підтримки середнього та малого бізнесу для збереження робочих місць. Слід зазначити, що ринок праці виявився чутливим до інституційних впливів і гнучко відреагував як на введення карантинних обмежень у березні-квітні (що проявилося зниженням сукупного попиту на робочу силу), так і на їх послаблення у травні-червні 2020 р. (що проявилося відновленням пропозиції робочої сили).

Інституційну реакцію на новітні соціальні загрози і ризики можна охарактеризувати як своєрідний стрес-тест у режимі реального часу, адже карантинні обмеження призвели не лише до скорочення доходів багатьох підприємств, але і до суттєвого зниження економічної активності і платоспроможності населення, погіршення його соціальних очікувань і зростання невизначеності. На жаль, зазначені урядові програми не виявили суттєвого впливу на доходи громадян, зокрема і через зниження інтенсивності трудової міграції та падіння рівня заробітної плати. Стримує відновлення робочих місць та зростання заробітних плат і ситуація з очікуванням другої хвилі пандемії. Також варто наголосити на скороченні доходів фізичних осіб-підприємців, які у 2019 р. формували близько чверті сукупного доходу громадян [9]. Отож, можна стверджувати, що різке скорочення споживання, зниження доходів, заощаджень і витрат населення, зниження товарної пропозиції у сферах торгівлі та послуг свідчать про значне погіршення добробуту українців.

Висновки і перспективи подальших досліджень у даному напрямі. Результати проведеного нами дослідження свідчать, що варіанти взаємодії чинників зовнішнього та внутрішнього характеру щодо інституційного впливу на соціальну безпеку людини можуть бути різними, що зумовлює різні сценарії інституційного регулювання рівня соціальної безпеки. За першим сценарієм держава може цілковито опікуватися соціальною безпекою людини, ставити у стратегіях розвитку відповідні цілі й досягати їх. За другим сценарієм держава через об'єктивні причини не може забезпечити повну соціальну безпеку громадян внаслідок нестабільної ситуації в Україні. Отож, можна стверджувати, що в умовах настання глобальних соціальних криз або інших загроз непереборної сили реалізація соціальної безпеки людини здійснюється вибірково, пріоритетом державного піклування стають найменш захищені верстви населення, тобто одночасно мають прояв різні варіації впливу соціальної безпеки держави на людину. Соціальна безпека людини має стати головним пріоритетом соціальної політики держави, цільовим орієнтиром діяльності громадянського суспільства в Україні.

У подальших дослідженнях доцільно проаналізувати ризики і небезпеки соціального характеру, 
спричинені впливом непереборних зовнішніх загроз, виявити можливі шляхи їх подолання та інструменти реалізації соціальної політики для своєчасного та ефективного запобігання небезпечним проявам.

\section{ЛІТЕРАТУРА}

1. Васильців Т. Г. Стратегічні пріоритети конвергенції соціальної безпеки України та СС / Васильців Т. Г., Лупак Р. Л. // Соціальноекономічні проблеми сучасного періоду України. 2018. - № 5. - С. 14-19.

2. Верховна Рада України. Про ратифікацію Конвенції Міжнародної організації праці про мінімальні норми соціального забезпечення № 102: Закон України від 16.03.2016 № 1024-VIII. URL: https://zakon.rada.gov.ua/laws/show/1024-19\#Text.

3. Вінічук М. В. Місце соціального аудиту в системі соціальної безпеки / Вінічук М. В., Марушко Н. С. // Соціально-правові студії. - 2018. - Вип. 1. - С. 148-157.

4. Державна служба зайнятості України. Ситуація на ринку праці. URL: https://www.dcz.gov.ua/ analitics $/ 68$.

5. Державна служба статистики України. Макроекономічні показники. URL: http://www.ukrstat.gov.ua/.

6. Іляш О. І. Стратегія та засоби конвергенції системи соціальної безпеки України та ЄС / Іляш О. I., Васильцев Т. Г., Лупак Р. Д. // Бізнес Інформ. 2018. - № 23 (491). - С. 8-14.

7. Кальницька М. А. Соціальна безпека: поняття та рівні дослідження / Кальницька М. А. // Демографія, економіка праці, соціальна економіка і політика. - 2017. - Вип. 17. - С. 566-571.

8. Коленда Н. В. Сутність механізму забезпечення соціальної безпеки населення / Коленда Н. В. // Економічні науки. Сер.: Економіка та менеджмент. - 2012. - Вип. 9(1.1). - С. 140-149.

9. Міністерство фінансів України. Макрофінансові показники. URL: https://minfin.com.ua/ua/.

10. Нечаєва I. А. Реформа системи соціального страхування як засіб зміцнення соціальноекономічної безпеки України в умовах перманентної кризи / Нечаєва I. А. // Державне управління: удосконалення та розвиток. - 2020. - № 4. URL: http://www.dy.nayka.com.ua/?op=1\&z=1634.

11. Новікова О. Ф. Інноваційні підходи до формування соціальної політики в умовах зростання зовнішніх та внутрішніх викликів / Новікова О. Ф. // Соціально-трудові відносини: теорія та практика. - 2014. - № 2. - С. 80-88.

12. Пенсійний фонд України. Видатки та доходи бюджету Фонду. URL: https://www.pfu.gov.ua/ statystyka/vydatky-ta-dohody-byudzhetu-fondu/.

13. Підлипна Р. П. Основні загрози та система соціальної безпеки в Україні / Підлипна Р. П. // Вісник Львівської комерційної академії. Серія економічна. -2015. - Вип. 47. - С. 20-23.

14. Харазішвілі Ю. М. Якість життя в системі соціальної безпеки України: індикатори, рівень, загрози / Харазішвілі Ю. М., Грішнова О. А. // Еко- номіка України. - 2018. - № 11-12. - С. 157-171.

15. Чечель А. О. Соціальна безпека в Україні: індикатори оцінки на регіональному рівні / Чечель А. О., Харланова Д. А. // Вчені записки Таврійського національного університету імені В. I. Вернадського. Серія: Економіка і управління. 2019. - № 30 (69). - C. 94-100.

16. Cutuli G., Grotti R. Heterogeneity in unemployment dynamics: (un)observed drivers of the longitudinal accumulation of risks. Research in Social Stratification and Mobility. - 2020. - Art. 100494.

17. Liotti G., Canale R. R. Poverty and Labour Market Institutions in Europe. Panoeconomicus. 2020. - Vol. 67 (3). - P. 277-290.

\section{REFERENCES}

1. Vasyl'tsiv, T. H. and Lupak, R. L. (2018), Stratehichni priorytety konverhentsii sotsial'noi bezpeky Ukrainy ta YeS, Sotsial'no-ekonomichni problemy suchasnoho periodu Ukrainy, № 5, s. 14-19.

2. Verkhovna Rada Ukrainy. Pro ratyfikatsiiu Konventsii Mizhnarodnoi orhanizatsii pratsi pro minimal'ni normy sotsial'noho zabezpechennia № 102: Zakon Ukrainy vid 16.03.2016 № 1024-VIII, available at: https://zakon.rada.gov.ua/laws/show/1024-19\#Text.

3. Vinichuk, M. V. and Marushko, N. S. (2018), Mistse sotsial'noho audytu v systemi sotsial'noi bezpeky, Sotsial'no-pravovi studii, vyp. 1, s. 148-157.

4. Derzhavna sluzhba zajniatosti Ukrainy. Sytuatsiia na rynku pratsi., available at: https://www.dcz.gov.ua/analitics/68.

5. Derzhavna sluzhba statystyky Ukrainy. Makroekonomichni pokaznyky., available at: http://www.ukrstat.gov.ua/.

6. Iliash, O. I. Vasyl'tsev, T. H. and Lupak, R. D. (2018), Stratehiia ta zasoby konverhentsii systemy sotsial'noi bezpeky Ukrainy ta YeS, Biznes Inform, № 23 (491), s. 8-14.

7. Kal'nyts'ka, M. A. (2017). Sotsial'na bezpeka: poniattia ta rivni doslidzhennia, Demohrafiia, ekonomika pratsi, sotsial'na ekonomika i polityka, vyp. 17, s. 566-571.

8. Kolenda, N. V. (2012), Sutnist' mekhanizmu zabezpechennia sotsial'noi bezpeky naselennia, Ekonomichni nauky. Ser.: Ekonomika ta menedzhment, vyp. 9(1.1), s. 140-149.

9. Ministerstvo finansiv Ukrainy. Makrofinansovi pokaznyky, available at: https://minfin.com.ua/ua/.

10. Nechaieva, I. A. (2020), Reforma systemy sotsial'noho strakhuvannia iak zasib zmitsnennia sotsial'no-ekonomichnoi bezpeky Ukrainy v umovakh permanentnoi kryzy, Derzhavne upravlinnia: udoskonalennia ta rozvytok, № 4, available at: http://www.dy.nayka.com.ua/?op=1\&z=1634.

11. Novikova, O. F. (2014), Innovatsijni pidkhody do formuvannia sotsial'noi polityky $\mathrm{V}$ umovakh zrostannia zovnishnikh ta vnutrishnikh vyklykiv, Sotsial'no-trudovi vidnosyny: teoriia ta praktyka, № 2, s. $80-88$. 
Вісник Львівського торговельно-економічного університету. Економічні науки. № 59, 2020

12. Pensijnyj fond Ukrainy. Vydatky ta dokhody biudzhetu Fondu, available at: https://www.pfu.gov.ua/statystyka/vydatky-ta-dohodybyudzhetu-fondu/.

13. Pidlypna, R. P. (2015), Osnovni zahrozy ta systema sotsial'noi bezpeky v Ukraini, Visnyk L'vivs'koi komertsijnoi akademii. Seriia ekonomichna., vyp. 47, s. 20-23.

14. Kharazishvili, Yu. M. and Hrishnova, O. A. (2018), Yakist' zhyttia v systemi sotsial'noi bezpeky Ukrainy: indykatory, riven', zahrozy, Ekonomika Ukrainy, № 11-12, s. 157-171.

15. Chechel', A. O. and Kharlanova, D. A. (2019), Sotsial'na bezpeka $\mathrm{v}$ Ukraini: indykatory otsinky na rehional'nomu rivni, Vcheni zapysky Tavrijs'koho natsional'noho universytetu imeni V. I. Vernads'koho. Seriia: Ekonomika i upravlinnia., № 30 (69), s. 94-100.

16. Cutuli G. and Grotti R. (2020), Heterogeneity in unemployment dynamics: (un)observed drivers of the longitudinal accumulation of risks, Research in Social Stratification and Mobility. Art. 100494.

17. Liotti G. and Canale, R. R. (2020), Poverty and Labour Market Institutions in Europe, Panoeconomicus, vol. 67 (3), r. 277-290.

Стаття надійила до редакизї 29 березня 2020 року 